\title{
French Burney: Some Notes on the Early Reception of Frances Burney's Novels in France ${ }^{1}$ \\ Carmen M. Fernández Rodríguez (cfernandezr@udc.es) \\ EOI A Coruña
}

\begin{abstract}
Frances Burney (1752-1840) was one of the main women writers in eighteenth-century Britain, where she cultivated the novel of manners and influenced Jane Austen herself. Burney's works deal with topics that have attracted the attention of gender and cultural studies from the 1980s onwards. This paper focuses on the reception of Burney's novels in France. After a proper contextualization of Burney's life and France in her oeuvre, I resort to Descriptive Translation Studies (DTS), and the ideas of French scholar Gérard Genette on the paratext, as well as the contributions of eighteenth-century scholars in the field of Burney Studies. I analyze the prefaces introducing the first translations of Burney's four novels into French and the reviews published in French newspapers at that time taking into account French poetics and the particular way in which Burney's works were versioned in France.
\end{abstract}

Keywords: Frances Burney, translation studies, France, eighteenth century, women's literature, polysystem theory.

\section{Resumen}

Frances Burney (1752-1840) fue una de las principales escritoras del siglo dieciocho en Gran Bretaña, donde cultivó la llamada "novel of manners" e influyó en Jane Austen. La obra de Burney incluye temas que han atraído la atención de los estudios de género y estudios culturales desde los años ochenta. Este artículo se centra en la recepción de las novelas de Burney en Francia. Tras una contextualización de la vida de Burney y Francia en su obra, se recurre a los Estudios Descriptivos de Traducción (EDT) y a las ideas del francés Gérard Genette sobre el paratexto, junto con las contribuciones de especialistas del siglo dieciocho en el campo de los 
"Burney Studies." Se analizan los prefacios presentando las primeras traducciones de las cuatro novelas de Burney al francés y las reseñas publicadas en las revistas francesas teniendo en cuenta la poética francesa y la forma concreta de traducir estas obras en Francia.

Palabras clave: Frances Burney, estudios de traducción, Francia, siglo dieciocho, literatura femenina, teoría de los polisistemas.

\section{INTRODUCTION}

There are many reasons to relate the English novelist Frances Burney (1752-1840) to France. Her mother, Esther Sleepe, was the child of French immigrants, and, after her mother's death, Frances was brought up by her maternal grandmother Mrs. Sleepe, née Dubois and a Roman Catholic. More importantly, the author of the best seller Evelina (1778) married the French General Alexandre-Jean-Baptiste Piochard D'Arblay and lived in France for ten years (1802-1812), which allowed Burney to move in high society with Madame de Maisonneuve and Louis Bonaparte, for instance. In France, Burney composed her pamphlet Brief Reflections Relative to the Emigrant French Clergy (1793), where she collapsed the religious distinctions between Roman Catholics and Protestants. The marriage to D'Arblay involved improving Burney's proficiency in a language that she was initially reluctant to speak in public and helped her to incorporate big excerpts in French to The Wanderer (1814), her masterpiece. In this novel the heroine is a French young lady by education who flees from the French Revolution and faces as much incomprehension as the book itself was to face in England. Its publication during a period of intense galophobia in Britain provoked the immediate reaction of reviewers who could not understand Burney's position towards France and condemned The Wanderer. ${ }^{2}$

Here I turn attention to a new and complex focus of interest within Burney Studies. I offer an introduction to Burney as a writer closely connected to France by exploring the way in which her novels entered the French literary polysystem. Janet Todd, who considers Burney as "the main painter of sentimental friendship in England and France in the late eighteenth century" (1980: 311), has argued that, in the 
eighteenth century, there was a back-and-forth relationship across the Channel that brought the two countries almost into one literary realm. Books of one nation were immediately translated and published in the other, creating a climate of mutual literary influence (Todd 1980: 5). After a contextualization of the author and eighteenth-century French poetics, the first prefaces and reviews of Burney's works will be examined following Itamar Even-Zohar's theory of the literary polysystem, Gérard Genette's idea of the paratext and the contributions of gender studies and eighteenth-century scholars. The former provides a theoretical framework that bears in mind all the elements of the literary system ${ }^{3}$ and explains how these elements are integrated and depend on each other. ${ }^{4}$ As for the poststructuralist scholar Gérard Genette, he defines the paratext as the physical layout and the group of verbal and non-verbal productions accompanying a text and guaranteeing its reception and consumption (1987: 7). A special area of transition between two elements of the polysystem the producer and the audience-, the paratext helps to analyze the complex textual apparatus where the elements of Even-Zohar's theory crystallize and interact. ${ }^{5}$

\section{METHODOLOGICAL FRAMEWORK AND THE FRENCH LITERARY POLYSYSTEM}

When Burney's books were published, the consumers of moral and pedagogical works were young female readers who should not be shown too violent passions or indecent heroines. As Stephen Botein and Martyn Lyons point out, the late eighteenth-century reading public consumed an increasing amount of recreational literature, as well as modern novels and the classics, like Defoe, Fielding and Richardson, and, in a later period, Gothic novels by 'Monk' Lewis and Ann Radcliffe. The French taste was supported by aristocrats and high-ranking members of the middle classes whose conservatism and beliefs were shaped from above. In general, the reading public was by far more limited than in England, where circulating libraries had a remarkable role in readers' taste and eighteenth-century editors supplied material that may have reinforced the readers' consciousness of belonging to a definable group with a definite social identity (Botein 1981: 469, 476-84; Lyons 2008: 45). These journals, critics and 
publishing houses were the aggregated factors conforming the institution in Even-Zohar's terminology, and they determined the translation strategies that reveal the relationships between translation cultures. Regarding the market and the repertoire, the French Revolution destroyed the structure and organization of the Ancient Regime book trade and brought to an end the royal privileges that had limited opportunities for publishers (Lyons 2008: 44).

Most translations of Burney's works were issued in Paris, but also in Geneva and the Low Countries, which were strategically situated for several reasons: they had a highly educated population and fostered multilingualism; the authors there were aware of the general issues concerned with how knowledge travels; and they were especially attentive to linguistic problems (Cook and Dupre 2012: 11, see also Freedman 2012: 4) while France offered "establishedness," joining various kinds of expertise (linguistic, theological and artisanal) together, and had accumulated an immense cultural capital that no emerging entity could afford to ignore. France was also an agent of indirect translation. According to Kate Chisholm, German and Dutch translations of Evelina appeared in 1779 and 1780, and, in 1796, the book crossed the Atlantic with the publication of an American edition (1998: 47). ${ }^{6}$

The advertisements or notices to Burney's works correspond to allograph and ulterior paratexts since they were not written by the author and they were added later, as if they were postfaces, and the functions and role of these paratexts become as important as the text itself (Genette 1987: 14). According to Annie Cointre, French préfaciers borrowed their model from ancient authors and some constant topoi justified the translator and introduced the English novel: praise of the author, summary, sociological moral and literary study, preorientation of reading, circumstances and reasons for the translation, which might include a summary of the translator's career, advertising aspects, etc. (2006: 6-7). This is basically the main structure in the paratexts of Burney's works.

An important aspect is that, in French translations, the aim was to satisfy the reader with interesting material without necessarily approaching the original. Translators corrected traits in order to 
accommodate it to the French taste and the linguistic and narrative elements considered as low and ordinary were erased from the text, as well as too violent or affective scenes. In this sense, the French repertoire selected the rules and materials governing both the production and the use of the product (Even-Zohar 1990: 18), that is, the new text, as les belles infidèles established: translation was envisioned as literary creation in and of itself and fidelity to the source text became secondary. Another point is that, from the seventeenth century onwards, critics praised simplified plots, the logical development of events from the beginning to the end and the maintenance of suspense, and that the novel had gained a reputation of being a light genre because it portrayed passions. Authors of prefaces still regarded novels as frivolous works affirming the superiority of French literature and Aristotelian principles and resisting dynamic canonicity or the introduction of foreign texts through their models (Even-Zohar 1990: 19). However, Wilhelm Graeber emphasizes that, towards 1750, domestication stopped being the norm and translators realized the charm of foreign literature: they were paradoxically adapting works to an audience who was totally uninterested in neoclassical precepts (1996: 307, 315). Burney's translations may be contextualized in the so-called "querelle des romans," a battle between conservative censors and novel fans, which meant that the faults of the English novels which were attacked by the French translators coincide with those of the English novels despised on the other side of the Channel.

\section{BURNEY'S TRANSLATIONS AND TRANSLATORS}

The first translators of Burney's works into French share some common features: all of them were travellers, artists or people with a certain contact with foreign texts; they translated very varied material (especially novels and books about travels and exploration); and some of them had posts of responsibility. Despite criticism, Burney was cherished and praised in French paratexts for her craft, her gender and her country, and she became so popular in France that a novel called Georgina, histoire véritable (Paris: Chez Maradan, 1788) was attributed to Burney and also Mrs Elizabeth Bennett's Les Imprudences de la jeunesse, par l'auteur de "Cécilia" (Mme d'Arblay), traduit de l'anglais 
par Mme la Baronne de Vasse (Paris: Buisson, 1788), apart from her halfsister Sarah Harriet's (called Sarah-Henriette in France) Le Jeune Cleveland (1815) and Voisins de la champagne (1820), which were the French versions of Traits of Nature (1812) and Country Neighbours (1820) respectively.

\subsection{Evelina}

Evelina's entrance in the French polysystem was more criticized than praised and revealed reviewers' inability to accept the English novel in France. After the first translation of Evelina as Evelina, ou l'Entrée d'une jeune personne dans le monde (1779) signed by Henri Renfer (17531819), ${ }^{7}$ more versions appeared by the same translator, both in Paris and Amsterdam (1780) and Geneva (1784). The first review of Renfer's translation appeared in L'Esprit des journaux français et étrangers, where Burney is considered Richardson's inheritor. Though Evelina is labeled a moral and literary work suitable for young people (1779: 395), it is criticized for its length. After summarizing the plot, reviewers incorrectly relate the dedication to Burney's mother. There were so many complaints about this first translation that, in 1786, a volume called Oeuvres de Miss Burney including Evelina appeared in London with the notice "Nouvellement traduit et rédigé avec beaucoup de soin d'après l'Anglois". ${ }^{8}$

In 1784, Griffet de la Baume (1756-1805) ${ }^{9}$ produced a translation of Evelina into French which included in its preface part of a review from Mercure de France where Evelina is considered as one of the best novels of the century and the emphasis is put on the author's desire to please her ailing father by composing the novel. This information contrasts with Burney's biographers, who maintain that the book was anonymously published and Dr. Burney discovered his daughter's authorship quite late (Doody 1988: 39). In the "Avant-propos" it is added that Evelina "languissoit dans les magasins des librairies, soit que la traduction française en fût trop défectueuse, soit que le public commençât à dédaigner ce genre d'ouvrage" (Cointre et al. 2006: 117). ${ }^{10}$ The work is reduced to two thirds and some changes are introduced: "[...] en retranchant tous ce qui nous a paru ne faire que des longueurs, des images trop familières ou rendues avec des expressions qui en dérobaient la finesse" (118). ${ }^{11}$ The suppressions in 
the text are justified: Burney uses the same devices all the time and ideas are repeated, but Burney's aim to please the reader is respected: "Cet ouvrage [...] ne peut manqué de plaire aux lecteurs délicats, puisqu'il a eu le bonheur de réussir avec tous ses défauts" (118). ${ }^{12}$ When years later Revue encyclopédie provides some information about Burney's three novels to that day and Brief Reflections, they praise "La vérité des caractères, l'agrément du style et l'intérêt des situations" (1802: 159) ${ }^{13}$ and also appreciate that the translation of 1784 was more faithful to the original text.

Reviews could turn out to be an excuse to criticize foreign fiction. In Bibliothèque universelle des Romans critics complained about the title of Burney's first novel since the heroine only makes minor mistakes and they added: "Sans doute ils [the English] savent peindre la scène, les costumes, \& conserver à chaque Acteur son habit, son geste, son ton: c'est l'imitation de la Nature, mais non pas de la Nature embellie. Les grâces leur sont inconnues; la bourgeoisie, qui figure toujours dans leurs Romans, a un accent si dur, des manières si chargées!” (1783: 4). ${ }^{14}$ English fiction was reduced to a mere composite of "Des bâtards, des enfans retrouvés, des paysannes, des mariages disproportionnés" (1783: $45)^{15}$ and was concerned with private life: "[...] leurs Romans sont moins chauds que les nôtres: mais ils ne sont pas froids; le ton de couleur qui règne dans leurs tableaux est toujours vrai" (1783: 104). ${ }^{16}$ Similarly, reviewers did not like the use of letters to tell the story: "Cette coupure jette trop de froideur, \& nécessite des reprises trop fréquentes" (1783: 8). ${ }^{17}$ They pay attention to Evelina's Urtext and comment on the behavior of Evelina's mother, Miss Evelyn —who forgot Villars's lessons-, and on Evelina's father, Sir John Belmont who was a monster. Again they discuss and summarize the plot. Evelina would again appear in French thanks to the editor, Maradan in 1797, and finally, much later, in 1843, another translation of Evelina by M. L. de Wailly came out in Paris with Charpentier.

\subsection{Cecilia}

Burney's consolidation as a canonic writer ran parallel to a more positive appreciation of her works, though some features were still criticized. According to Catherine Parisian, who has tracked the textual transmission of Burney's Cecilia in the French context, this 
novel originated both literal and abridged translations and its entrance into France as Cecilia ou Mémoires d'une héritière was supported by a renowned critic, Pierre Ambroise François De Laclos (1741-1803). Burney scholar Margaret Anne Doody highlights that this writer enjoyed Cecilia to the point of modeling the character of Cécile in Les liaisons dangereuses on Evelina (1988: 146), and he signed the reviews of Henri Rieu's translation in $1783 .{ }^{18}$ De Laclos's opinion appeared in a landmark representative of the French institution, Mercure de France, which comprised letters, stories, poems, theatre reviews, and commentaries on the literary world to please an educated readership fascinated by the Paris salons. By all means, the publication greatly facilitated Burney's entrance in the field of prestigious foreign authors in France, and De Laclos's first article, which was published on 3 April, was introduced by a long digression on romance, history and the theatre stating that women are better endowed to write romances: "Leur éducation, leur existence dans la société, toutes leurs qualités louables, \&, s'il faut tout dire, quelques uns même de leurs défauts, leur promettent, dans cette carrier, des succès que, selon nous, elles chercheroient vainement dans toute autre" (1784a: 108). ${ }^{19}$

De Laclos brands Burney one of the most distinguished "romanciers" (1784b: 110) despite the bad quality of the translation, an aspect that is repeatedly emphasized. In the preface to Henri Rieu's 1785 translation of Cecilia, there is an "Avis de l'éditeur" where it is stated that the first translation (1783) was very defective and both the excessive length and the attention to detail are condemned. Besides, the number of changes and the suppression of paragraphs, which contributed to enliven narration in the original, have disappeared (Cointre et al. 2006: 119). According to this "Avis," Cecilia needed being corrected to be acceptable in France and the result has definitely not been successful (119). Journal du Lycée also attacked the first translation of Cecilia for having distorted the original, and they prayed readers not to judge Burney for this translation. Years later, critics stated in Biographie des hommes vivants that "[t]ous les romans de miss Burney ont été traduits en français; mais ils ne l'ont pas tous été avec le soin qu'ils méritent" (1816: 553). ${ }^{20}$

As for the technique and characters, De Laclos considers Cecilia "d'une grande conception et d'un vif intérêt; qu'il possède 
éminemment le mérite de repeindre les mœurs et les usages; qu'il est rempli d'observations fines et profondes; qu'en général, les caractères y sont vrais et bien soutenus; que la morale en est attrayante et pure" (Cointre et al. 2006: 119-20). ${ }^{21}$ Still, he has some reservations about the novel. While some reviewers condemned the excessive passion in Burney, De Laclos, on the contrary, misses some sexual tension in Cecilia. He complains about Mortimer's little sex appeal and admires Belfield (De Laclos 1784d: 106). In another review he explains that the first volume of Cecilia was attacked for being too cold (1784c: 153). The French author attributes many misunderstandings between the French spouses to a lack of confidence: "ce silence, qui nous paroît extraordinaire, ne passât pourtant point les bornes de la vraisemblance dans les mours Angloises" (1784d: 106). ${ }^{22}$ According to De Laclos, the defaults in Cecilia are the repetition of the same features, the predominance of superfluous details and the appearance of useless characters. Nevertheless, he places Cecilia among the best works with the exception of Clarissa (1747-8), Tom Jones (1749) and Julie ou La Nouvelle Heloise (1761) (De Laclos 1784c: 119-20).

Reviewers of Revue encyclopédie stated about Cecilia: "La fable est plus fortement conçue, le dénouement prépare et suspend avec plus d'art, et l'auteur s'élève, dans plusieurs morceaux, à côté de Richardson et de Fielding" (1802: 159). ${ }^{23}$ Galerie historique also focused on the technical virtues of Cecilia, Burney's masterpiece: "la sagesse du plan, la vérité et la diversité des caractères, la connaissance profonde des vices et des ridicules de la société, un intérêt touchant, qui quelquefois s'élève au plus grand pathétique, un dialogue spirituel et animé, assurent à cet ouvrage un rang distingué parmi les compositions de ce genre" (1822: 61). ${ }^{24}$

\subsection{Camilla}

In general, Camilla enjoyed a better reception than Burney's previous novels. Jean-Baptiste Denis Després (1752-1832) ${ }^{25}$ and Jacques-Marie Deschamps (1750-1826) ${ }^{26}$ versioned it into French, a work which appeared just five months before the publication of MarcAuguste and Charles Pictet's translation of some parts of Camilla in Bibliothèque Britannique (Fernández 2011: 232). Burney's work was described in Revue encyclopédie as a flawed novel because it did not 
conform to French vraisemblance: "l'histoire est sans cesse entravée pas des incidents superflus. L'un des principaux personnages est d'une bonhomie qui ressemble à la bêtise; et les amours d'Edgar et de Camilla se traînent d'une manière aussi impatiente que peu vraisemblable" (1802: 161). ${ }^{27}$

While the 1797 translation of Camilla did not contain any paratextual element similar to a preface, the second edition which came out a year later was introduced by an "Avertissement" explaining the importance of the work for two reasons: its author and its country. For the préfaciers of Camilla in 1798, Burney shows her deep understanding of the human heart: "A tout moment le Lecteur y retrouve Miss Burney dans une foule de vérités de sentimens [sic] mêlés à ses récits, dans une philosophie douce, aimable, toujours en action, toujours pleine de leçons utiles pour tous les âges, et surtout dans un grand respect pour les mœurs" (Burney 1798: ii-iii). ${ }^{28}$ Although they have suppressed some parts, they remark that "on s'est bien garder de rien supprimer de tout ce qui peut servir au jeu des passions et au développement des caractères" (Burney 1798: iii). ${ }^{29}$ Additionally, English material was fashionable and English novelists had always offered "la peinture fidèle des mœurs, des caractères et de la société" (Burney 1798: i). ${ }^{30}$ Two characters were especially important for the plot, Sir Hugh and Eugenia Tyrold. About the English society, in Revue Britannique, it is added that Burney was the novelist who encapsulated its essence best: "[...] [elle offre des éléments de durée, de moralité, de grandeur que l'on ne saurait trop étudier; sans doute il y a là un singulier mélange de bizarrerie, d'excentricités, mais ce mélange achève de lui donner un caractère piquant qui intéresse l'observateur" (1852: 2). ${ }^{31}$

\subsection{The Wanderer}

The Wanderer was rendered into French as La Femme errante ou Les Embarras d'une femme (1815) by one of the pupils of the stenographer Theodore-Pierre Bertin, Baptiste Joseph Breton de La Martinière (1777-1852), ${ }^{32}$ and an interpreter at the courts, Auguste-Jacques Lemierre d'Argy (1762-1815). ${ }^{33}$ It seems that Burney did not like this translation since she described it as "abominable" in a letter dated 30 January 1815 (Burney 1991: xxix). 
The review of La femme errante in Mercure de France introduces Burney as a successful novelist and a summary of the novel is given. The English author is defined in the following terms: "Douée d'un esprit fin et observateur, miss Burney, possédait ce don heureux de la nature, qui nous permet de transmettre aux autres, d'une manière piquante, les impressions que nous recevons des objets qui frappent nos yeux" (1815: 339). ${ }^{34}$ However, the translation was not praised because the style is trivial and repulsive: "Madame de la Fayette comparait les sots traducteurs à des laquais qui changent en sottises les complimens $[s i c]$ dont les chargent leurs maîtres. Miss Burney méritait un meilleur interprète" (1815: 347). ${ }^{35}$

\section{CONCLUSION}

It is clear that France played a decisive role in Burney's life and career, as the evolution of her name, from Frances Burney to Mme. D'Arblay, shows. The author's ambivalent portrayal of France and her stance towards her husband's homeland were never positively accepted in Britain, an attitude which contrasts with the continental critics' praise of Burney's craft and approach to the novel as a genre, her gender and her nationality since English books were all the rage in France at the end of the eighteenth century.

For Burney's scholars, France should be a strategic point of departure for further analyses for two reasons: firstly, these translations meant the incorporation of one canonical English author into a prestigious and distinct literary polysystem. In comparison with France, Great Britain represented a more receptive milieu where authors of very different ideas and social status were actively engaged in shaping the novelistic genre. Secondly, and as Even-Zohar points out (1990: 67), France was also a relevant agent of indirect translation since success there was the passport to enter other literatures (Spanish, German, etc).

Thanks to the readers' and the publishers' interest, Burney became an English classic in the French repertoire. This analysis has shown that Burney's oeuvre was subjected to some common practices of French editors who used to take material from reviewers to 
introduce new works into the French market. Burney's novels appeared in France on the eve and aftermath of the Revolution, when there was an outbreak of pamphlets, journals and political broadsides that which opened up publishing and every other industry to the forces of free enterprise and open competition. Besides, the reception of Burney's novels becomes clear evidence of the coexistence of neoclassical precepts and liberalizing tendencies in the French repertoire. The English writer was never attacked for her novels, but for the way they were presented to French consumers, either because the quality of the translation was not good or because English poetics departed much from the French conception of literary works. Thus, Burney's novels were immediately subjected to diverse content and stylistic modifications to render the texts acceptable for French consumers, but at the cost of sacrificing the original works and the author's genius.

\section{NOTES}

${ }^{1}$ This essay is part of the outcome of the University of A Coruña research network "Rede de Lingua e Literatura Inglesa e Identidade III” ED431D2017/17.

${ }^{2}$ See Tracy Edgar Daugherty (1988: 163) and John Wilson Croker's opinion in The Quarterly Review (1814: 124, 130).

3 This concept is defined as "The network of relations that is hypothesized to obtain between a number of activities called literary, and consequently these activities themselves observed via that network" (Even-Zohar 1990: 28).

4 “Thus, a CONSUMER may 'consume' a PRODUCT produced by a PRODUCER, but in order for the 'product' (such as 'text') to be generated, a common REPERTOIRE must exist, whose usability is determined by some INSTITUTION. A MARKET must exist where such a good can be transmitted" (Even-Zohar 1990: 34).

${ }^{5}$ The paratext is the "[...] lieu privilégié d'une pragmatique et d'une stratégie, d'une action sur le public au service, bien ou mal compris et accompli, d'un meilleur accueil du texte et d'une lecture plus pertinente plus pertinente, s'entend aux yeux de l'auteur et de ses alliés" (Genette 1987: 8). "[P]rivileged place of a pragmatics and a strategy, of an influence on the audience that, either well or poorly understood, is at the 
service of a better reception for the text and a reading more pertinent in the eyes of the author and his/her allies" (translations from French are mine).

${ }^{6}$ As Carmen Fernández (2008) has argued, in Spain, Evelina was anonymously translated in 1825 together with El leproso de la ciudad de Aosta by Xavier de Maistre, a French writer opposed to the French Revolution, in a volume printed in Paris by Rigoux, and, seven years later, a new edition appeared in Madrid translated and corrected by D.R.M. for the publishing house Boix.

${ }^{7}$ Refner was a translator and a diplomat who lived in Berlin and The Hague. He had already translated L'Alliance des princes de l'Empire germanique (1786), Essay sur les accusations intentées aux Templiers et sur le secret de cet ordre (1783) from German, as well as several descriptions of animals written by Arnout Vosmaer.

8 Translation: "Recently translated and carefully rewritten from English."

${ }^{9}$ Griffet de la Baume wrote comedies, poems and a biography of Daniel Defoe, apart from collaborating in several periodical publications and translating from German and English, for example Suite et fin de Tristam Shandy (1795), La Victim de l'imagination (1795), R. M. Roche's Les Enfants de l'abbaye (1801) or Thomas Payne's Le Sens comun (Cointre et al. 2006: 117).

${ }^{10}$ Translation: "languished in the bookshops stores either because the French translation was too faulty or because the audience began to despise this kind of work."

${ }^{11}$ Translation: "we have removed all that we thought were only long sentences, too familiar images or images rendered with expressions that deprived of delicacy."

12 Translation: "This work [...] cannot but please delicate readers because it has succeeded despite its faults."

${ }^{13}$ Translation: "The authenticity of characters, the approval of style and the interest of situations."

${ }^{14}$ Translation: "Undoubtedly they can paint the scenery, the customs, and preserve the clothes, gestures and ton for each actor: it is the imitation of Nature, but not embellished Nature."

${ }^{15}$ Translation: "Illegitimate children, lost children that are found, peasants, disproportioned marriages."

16 Translation: "their novels are less warm than ours, but they are not cold, the presiding cast of their pictures is always authentic." 
${ }^{17}$ Translation: "This interruption provides too much coldness and the need to resume too frequently."

${ }^{18}$ Henri Rieu (1727-1781) was a Swiss army officer and translator, as well as the Commander of the French part of St. Martin Island in the Caribbean. Rieu also versioned Joseph Baretti's Voyage de Londres à Gênes (1777) and John Moore's Lettres d'un voyageur anglois sur la France, la Suisse et l'Allemagne (1781), and J.G. Lavater's Essai sur la Physionomie (together with Mme de la Fite and M. Gaillard, 1781). Voltaire bequeathed all his books in English to Rieu and he was the godfather of the Swiss Orientalist Charles Pierre Henri Rieu. According to Parisian, abridged editions of Cecilia in France were not as successful as Rieu's and they did not enjoy great circulation either (2012: xliii).

${ }^{19}$ Translation: "Their education, their existence in society; all their amiable qualities, and, to say the truth, even their bad points promise such a success in their school that they would unsuccessfully look for them in another."

${ }^{20}$ Translation: "all the novels by Miss Burney have been translated into French; but not all them have been translated as they merit."

${ }^{21}$ Translation: "with a great concept and strong interest; it has the merit to repaint the customs and traditions; it has plenty of delicate and deep remarks; in general, its characters are authentic and well sustained, the moral message is attractive and pure."

${ }^{22}$ Translation: "this silence, which seems to us extraordinary, never goes beyond the limits of verisimilitude in English customs."

23 Translation: "The fable is more strongly conceived, the conclusion prepares and creates intrigue with more skill, and in many extracts the author reaches the level of Richardson and Fielding."

${ }^{24}$ Translation: "the good sense of the idea, the authenticity and diversity of characters, the deep knowledge of the vices and absurdity of society, a touching interest, which sometimes reaches the pathetic, the spiritual and lively dialogue, guarantees this work a distinguished place among the compositions of its genre."

${ }^{25}$ A journalist specialized in politics, an accomplished writer and a librettist, Després became secretary of Louis King of Holland who made him a councilor of state (Thomas 2009: 754). He translated Le Moine (1793), Les Mystères d'Udolphe (1794), Oeuvres d'Horace (1821), David Hume's Histoire d'Angleterre depuis l'invasion de Jules-César jusqu'a la revolution de 1688 (1825-7) and Elizabeth Inchbald's Simple Histoire (1826). 
${ }^{26}$ Deschamps was a dramatist, a librettist and a playwright who also translated Elizabeth Inchbald's Lady Mathilde (1793) and Simple Histoire (1796, two vols.) and Vicenzo Monti's poem Le Barde de la Forêt-Noire (1807) apart from working for Clément's de Dijon's Journal Littéraire.

${ }^{27}$ Translation: "the story is continually hindered by superfluous incidents. One of the main characters is so good-natured that he looks a brute; and the love between Edgar and Camilla is dealt with in a way as boring as difficult to believe."

${ }^{28}$ Translation: "The reader always finds Miss Burney in a crowd of true feelings confused in her novels, he finds a sweet philosophy working all the time and plenty of lessons useful for all the ages, and all over, he finds a great respect for customs."

${ }^{29}$ Translation: "We have taken care not to suppress all that serves for the game of passions ant the development of characters."

${ }^{30}$ Translation: "the faithful picture of customs and characters in society."

${ }^{31}$ Translation: "she offers elements of duration, morality, and grandeur which we could not sufficiently analyze; undoubtedly, there is a singular mixture of oddity and eccentricity, but this mixture provides an original quality which interests the observer."

${ }^{32}$ Breton de la Martinière became a parliamentary stenographer and worked for The Gazette de France and Journal de Paris. He was one of the founding members of Ga:ette des tribunaux and a permanent collaborator of Moniteur universel. Thanks to his proficiency in almost all the European languages, he obtained a post as official interpreter at court. As a translator, he produced Voyage d'Egypte et de Nubie (1755), Bibliothèque portative de voyages (1817), Kotzebue's Romans, contes, anecdotes et mélanges (1810), Contes moraux anglais (1802), Benjamin Franklin's Correspondance inédite et secrète (1817) and Heinrich Campe's Les Soirées sous le vieux tilleul (1815).

${ }^{33}$ Lemierre d'Argy was a librarian and wrote popular plays. He translated Nouveau code criminal de l'empereur (1787), Mémoires de la reine d'Etrurie Marie-Louise de Bourbon (1814) and Samuel Jackson Pratt's L'Élève du plaisir (1787).

${ }^{34}$ Translation: "Endowed with a delicate and observing spirit, Miss Burney has that happy gift of nature which allows transmitting to the rest of people in an original way the impressions that we receive of the objects that surprise us." 
35 Translation: "Madame de la Fayette compared stupid translators with the footmen who turn into nonsense the compliments their masters tell them. Miss Burney deserved a better interpreter."

\section{WORKS CITED}

Botein, S.J., R. Censer and H. Ritvo. 1981. "The Periodical Press in Eighteenth-Century English and French Society: A CrossCultural Approach." Comparative Studies in Society and History 23.3 (July): 464-90.

Burney, F. 1779 (1778). Evelina, ou l'Entrée d'une jeune personne dans le monde. Traduit de l'anglois par H. Renfner. Paris et Amsterdam: D.-J. Changuion.

Burney, F. 1784 (1778). Evelina. Par Griffet de la Baume. Bouillon: Societé Typographique.

Burney, F. 1783 (1778). Cecilia ou Mémoires d'une héritière. Par l'auteur d'Evelina. Traduits de l'anglois. Neuchatel: Imprimerie de la Société typographique, \& a Geneve, chez Barthelemi Chirol. 5 vols.

Burney, F. 1793. Brief Reflections Relative to the Emigrant French Clergy: Earnestly Submitted to the Humane Consideration of the Ladies of Great Britain. London: T. Davidson.

Burney, F. 1797 (1796). Camilla, ou La Peinture de la jeunesse. Traduit de l'anglais de Miss Burney par J.-B. Denis Després et J.-Mar. Deschamps. Paris: Maradan, 5 vols.

Burney, F. 1798 (1796). Camilla, ou La Peinture de la jeunesse. Seconde édition revue et corrigée par les cits. D...ps et D...s. Oeuvres de Miss Burney. Tome huitième. Paris: Maradan.

Burney, F. 1814 (1815). La Femme errante ou Les Embarras d'une femme, par Miss Burney. Traduit de l'anglais par Jean Baptiste Joseph Breton de La Martinière et Auguste-Jacques Lemierre d'Argy. Paris: Chaumerot, 5 vols.

Burney, F. 1814 (1991). The Wanderer. Ed. Margaret Anne Doody, Robert L. Mack and Peter Sabor. Oxford: Oxford University Press.

Chisholm, K. 1998. Fanny Burney: Her Life 1752-1840. London: Chatto and Windus.

Cointre, A. et al., eds. 2006. Recueil de prefaces de traducteurs de roman anglais (1728). Saint-Etienne: Université de Sain-Étienne. 
Cook, H.J. and S. Dupre, eds. 2012. Translating Knowledge in the Early Modern Low Countries. Münster: LIT Verlag.

Croker, J.W. 1814. "Review of The Wanderer." The Quarterly Review 11 (April): 123-30.

Daugherty, T.E. 1988. Narrative Techniques in the Novels of Fanny Burney. New York: Peter Lang.

De Laclos, C. 1784a. Rev. of Cecilia ou Mémoires d'une héritière. Mercure de France 3 avril, 103-10 and 153-65.

De Laclos, C. 1784b. Rev. of Cecilia ou Mémoires d'une héritière. Mercure de France 17 avril, 103-10.

De Laclos, C. 1784c. Rev. of Cecilia ou Mémoires d'une héritière. Mercure de France 24 avril, 152-65.

De Laclos, G. 1784d. Rev of Cecilia ou Mémoires d'une héritière. Mercure de France 15 mai, 102-20.

Doody. M.A. 1988. Frances Burney: The Life in the Works. Cambridge: Cambridge University Press.

Even-Zohar, I. 1990. "The Literary Polysystem.” Poetics Today 11: 9-44. Even-Zohar, I. 1990. "Laws of Literary Interference." Poetics Today 11: 53-72.

Fernández Rodríguez, C.M. 2008. "Fanny Burney and Spain: The View from Universidade da Coruña." The Burney Letter 14.1: 16-7.

Fernández Rodríguez, C.M. 2011. "A Genevan Camilla: The First Translation of Frances Burney's Camilla into French.” The Grove: Working Papers on English Studies 18: 225-42.

Freedman, J. 2012. Books without Borders in Enlightenment Europe: French Cosmopolitanism and German Literary Markets. Pennsylvania: University of Pennsylvania Press.

Galérie historique des contemporaines. 1822. Volume trois. Seconde édition. Bruxelles: Aug. Wahlen et Comp, ImprimeursLibraires.

Genette, G. 1987. Seuils. Collection Poétique. Paris: Éditions du Seuil.

Graeber, W. 1996. "Les Charmes des fruits défendus: Les Traductions de l'anglais et la dissolution de l'idéal classique," in M. Ballard andet L. D'Hulst, eds. La traduction en France à l'âge classique. Lille: PUS. 305-319.

Lyons, M. 2008. Reading Culture and Writing Practices in Nineteenthcentury France. Toronto, Buffalo and London: Toronto University Press. 
Parisian, C. 2012. Frances Burney's Cecilia: A Publishing History. Farnham, Surrey: Ashgate.

Rev. of Evelina. Gentleman's Magazine 48 (Sept. 1778): 425.

Rev. of Evelina. 1779. L'Esprit des journaux français et étrangers 1 (Janvier) : 395-7.

Rev. of La femme errante. 1815. Mercure de France 62 : 338-47.

Revue encyclopédique ou Journal des Sciences, des Lettres et des Arts. 1802. Tome trois. Paris: Chez Fucus.

Thomas, J. 2009 (1887). The Universal Dictionary of Biography and Mythology. Vol 2. New York: CLU-HYS.

Todd, J. 1980. Women's Friendship in Literature. New York: Columbia University Press.

Van Tieghem, P. 1966. L'Année littéraire (1754-1790) comme intermédiaire en France des littérature étrangères. Genève: Slatkine Reprints.

West, C.B. 1932. "La Théorie de la traduction au XVIII siècle par rapport surtout aux traductions françaises des ouvrages anglais." Revue de Littérature Comparée 12: 330-55. 